\title{
The International Association for Danube Research (IAD) - portrait of a transboundary scientific NGO
}

\author{
Jürg Bloesch
}

Received: 26 March 2009 /Accepted: 31 March 2009/Published online: 9 May 2009

(C) Springer-Verlag 2009

\begin{abstract}
Introduction The International Association for Danube Research (IAD), a legal association (Verein) according to Austrian law, presently consists of 13 member countries and 12 expert groups covering all water-relevant scientific disciplines. IAD, founded in 1956, represents a traditional and significant stakeholder in the Danube River Basin, fulfilling an important task towards an integrative water and river basin management requested by the EU Water Framework Directive.

Discussion IAD, stretching between basic and applied research, adapted its strategy after the major political changes in 1989. IAD fosters transdisciplinary and transboundary projects to support integrative Danube River protection in line with the governmental International Commission for the Protection of the Danube River (ICPDR) in which IAD has had observer status since 1998. Recent scientific outputs of IAD encompass, amongst others, a water quality map of the Danube and major tributaries, the Sturgeon Action Plan, hydromorphological mapping of the Drava, a macrophyte inventory, and a Mures River study. Further information about IAD can be found on our website http://www.iad.gs.
\end{abstract}

Keywords Aquatic research - Danube River Basin . Environmental NGO $\cdot$ History .

International Association for Danube Research (IAD)

Responsible editor: Walter Giger

\footnotetext{
J. Bloesch $(\bowtie)$

Swiss Federal Institute of Aquatic Science and Technology (Eawag),

Überlandstrasse 133,

Dübendorf, Switzerland

e-mail: bloesch@eawag.ch
}

\section{Introduction}

The Danube River Basin (DRB) officially encompasses 19 countries, four of which have only very small areas of headwaters (Albania, Macedonia, Italy, and Poland). This figure includes the recently emerged Montenegro, while Kosovo as the newest independent state would increase the Danube countries to 20. This is by far the largest number on the global scale featuring a great variety of cultures and mentality, which makes transboundary issues extremely difficult and challenging, although people in the DRB have developed a kind of solidarity as "Danubian countries." Whether the country borders are along the river (as over some $800 \mathrm{~km}$ between Romania and Bulgaria) or across the river (creating the well-known upstream-downstream situation) makes a significant difference. A meandering river does not respect a political border established in the middle of the channel and shifts from one country into another (as, e.g., in the lower Mura/Drava floodplains). While these problems are being solved on the political level by bilateral border commissions and governmental mapping agencies, the International Commission for the Protection of the Danube River (ICPDR, http://www.icpdr.org) is the official forum where issues of water protection and conservation are treated since 1998. ICPDR with its expert groups jointly prepares projects and documents for implementation to be ratified by the national governments and is actively supported by many nongovernmental organizations (NGOs) such as the IAD having observer status, which is fostered by public participation programs.

The DRB lies in the historical "political fault" between east and west, reflecting the battles between Asian and Turkish empires and European states, and finally represented by the "Iron Curtain" between capitalistic and communist countries. The different political systems have 
greatly influenced social behavior, technical development, as well as water use and protection. Today, we can illustrate the situation by the fact that, in the Upper Danube (west), we have mostly "clean water in destroyed channels," while in the Middle and Lower Danube (east), we have "polluted water in more intact channels" (Bloesch 1999). As a consequence of the recent political development, the Middle and Lower Danube countries in transition are or are gradually becoming members of the European Union. Hence, economic pressure in these countries will dramatically increase and subsequent development may severely impact near natural stretches and floodplains of the Danube River and its major tributaries (Sava, Drava, and Tisza).

The Danube River is also the geographical border between east and west. The Ponto-Caspian relicts are still an important part of the natural fauna. However, the nuisance of invasive neozoans and neophytes threatening native species is prominent, as the trans-European waterway system links the Danube River with the Rhine River and promotes the exchange of plants, benthos, and fish across large river basins (Bloesch and Sieber 2003).

\section{IAD, the oldest Danubian NGO}

In 1956, the Viennese Reinhard Liepolt founded the International Association for Danube Research (IAD, Internationale Arbeitsgemeinschaft Donauforschung) in the frame of the XIII Congress of the Societas Internationalis Limnologiae (SIL) in Helsinki. While the global SIL (http://www.limnology.org) provided an umbrella and acted as the roof organization, IAD made the "iron curtain" semipermeable for scientific experts of Western and Eastern Europe. During the aspiring times after the Second World War, it was necessary to support and coordinate the increasing activities in the fields of limnology, water resources management, and protection against pollution in the DRB. With persistence, Liepolt followed his goals through the Academy of Sciences, national committees, ministries, and scientific institutes, and linked Danube scientists from Austria, Switzerland, Germany, and all the riparian countries downstream, to the former Soviet Union in cooperative activities.

Member country representatives regularly meet in international IAD conferences hosted in a given sequence by all countries. The papers presented are published in the IAD Conference Proceedings (as for example Teodorović et al. 2004), formerly the series "Limnologische Berichte Donau" (Limnological Danube Reports). Main conference topics reflecting the actual and hottest issues of limnological research and water management show the temporal variation of the key focus of IAD. Major scientific output was the monograph "Limnologie der Donau" in 1967 (Liepolt 1967) and the "Bibliographie der Donau" in 1986 (Godeanu and Popescu-Marinescu 1986). After 1990, four volumes of the book series "Ergebnisse der DonauForschung" (Results of Danube Research) have been published (IAD 1990, Weber 1993, Schmid 1994, KuselFetzmann et al. 1998). Since 1999, the IAD-Bulletin "Danube news/Donau aktuell" reports on actual IAD activities in the DRB (Danube News 2008). Recently, some special issues of "Archiv für Hydrobiologie"/Supplement "Large Rivers" (formerly "Donauforschung") reflected main research topics of IAD (Janauer et al. 2003, Bloesch 2005, Hein et al. 2008). Since 2004, the IAD literature (some 600 titles) is hosted by the Library of the University of Vienna (http://www.univie.ac.at/fb-biologie).

After the fall of communism in 1989, major political changes significantly affected issues of water protection, too. IAD had to adapt its strategy as in 1998 the ICPDR took over the international coordination on a governmental level. IAD became one of the first observers in ICPDR where it brings in scientific expertise in the various ICPDR expert groups. For example, today, IAD strives towards innovative steering and coordination of water research in the DRB, including the implementation of joint projects by scientific representatives of the 13 member countries: Germany, Switzerland, Austria, Slovakia, Czech Republic, Hungary, Croatia, Bosnia-Herzegovina, Serbia, Bulgaria, Romania, Ukraine, and Moldova. National IAD committees exist in Austria (since 1976, http://www.oen-iad.org), Serbia (since 2003, http://www.iad.org.yu), and Romania (since 2007). They develop their own independent NGO activities that are, however, in line with the general framework of IAD.

\section{Main research activities of IAD for a healthy Danube}

In the 1950 s to $1990 \mathrm{~s}$, a main focus in the DRB was organic pollution and, hence, chemical and biological monitoring of streams and rivers was an imperative task. IAD took a strong position in plankton and benthos inventories and investigations that were applied in the saprobic system, mainly developed by the Czech Vladimir Sládeček (1973). IAD accumulated a lot of taxonomic expertise - the scientific basis of biodiversity - that culminated in the publication of a map of the biological water quality of the Danube River (Fig. 1; Schmid 2004). This is still the only existing overall DRB quality map based on saprobiology. The Upper Danube is mainly water class II (moderately polluted), while the Middle Danube is class IIIII (critically polluted). Downstream of Vienna, large cities and industries are the important sources of nutrients and toxicants, thus turning the large tributaries into classes III 
and IV (heavily to excessively polluted). However, the high discharge and self-purification capacity of the Danube River keeps the Lower Danube mostly between class II and III.

Presently, IAD has 12 expert groups covering all major fields of aquatic sciences. Ecological studies, particularly long-term analyses to improve the water quality and conserve or restore the ecomorphological structure of the Danube and its tributaries, are in the main focus of IAD. It is crucial for transboundary rivers, such as the Danube, that analytical methodologies are standardized and meet existing (European) norms, from sampling methods, conservation, preparation, and analysis of samples up to data processing, evaluation, and documentation of results. Stretching between basic and applied science, one of IAD's main objectives is to investigate the damage and negative trends in the aquatic ecosystem, to develop ecological concepts and models for river management, and to inform the public of the urgency of improvements.
Fine examples of IAD activities, which are part of a detailed work program developed in 1997, are:

- Applying ecotoxicological and long-term and shortterm bioaccumulation tests to monitor contaminant concentration (Wachs 2000, Teodorović et al. 2000);

- Investigating river sediments contaminated by toxic pollutants and applying multidisciplinary (abiotic and biotic) assessment criteria of heavy metal contamination (Dalmacija et al. 2006);

- Applying new biomonitoring techniques by using automatic monitoring stations as early accident warning systems of organic and other pollutants. For example, online measurement stations equipped with continuous biotests (luminescent bacteria, Scenedesmus algae, Dreissena mussels) are established in the Rivers Naab and Danube (Wachs and Kopf 1996). Also, biomarkers such as methallothionein in chloride cells and vitellogenin in livers of fish are being used to detect sublethal effects of heavy metals and hormone-active substances,

\section{Water quality of the Danube and its tributaries 2002}

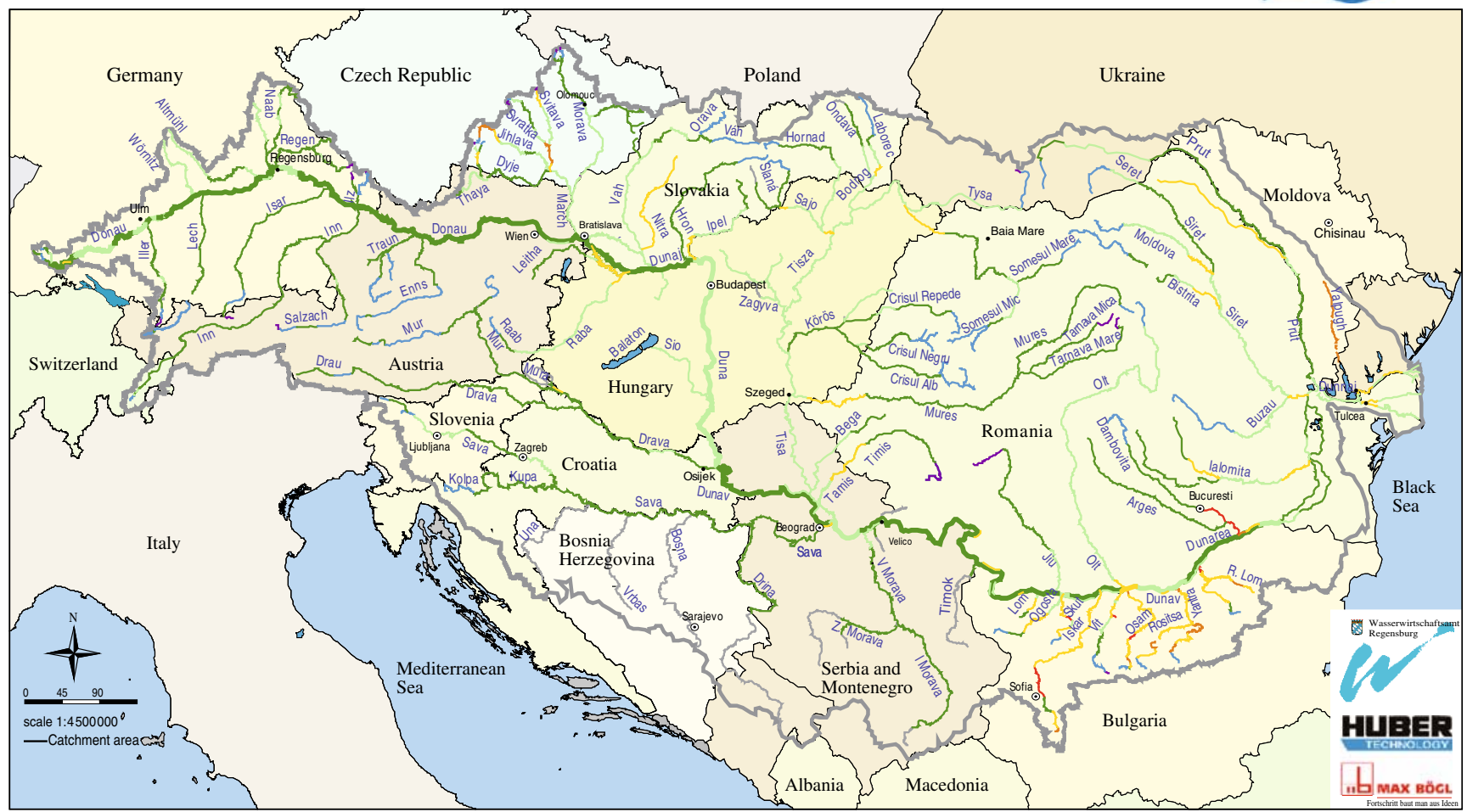

Fig. 1 Water quality map of the River Danube and its tributaries (2002) based on biological-ecological investigations that are supplemented by chemical and physical measurements (modified from Schmid 2004). While the Upper Danube is moderately polluted, the tributaries in the Middle and Lower Danube are heavily polluted; however, dilution keeps the Danube critically polluted. Detailed information is given on the original map which can be ordered from the IAD General Secretariat (http://www.iad.gs) or from the State Office for Regional Water Management, Regensburg (poststelle @wwa-r.bayern.de). Download as pdf file from http://www.wwa-r. bayern.de/fluesse_und_seen/datengewinnung/gewaesserqualitaet_ fluesse/karten_und_berichte/index.htm 
Border of catchment area

Border of countries

\section{River quality classes}

\section{Class I: unpolluted to very slightly polluted (oligosaprobic)}

River reaches with clean water, with oxygen permanently near saturation level and low nutrient load; low bacteria concentration; moderately dense colonization mainly by algae, mosses, flatworms, and insect larvae; water cool in summer - suitable for spawning of salmonids

\section{Class I-II: slightly polluted (oligosaprobic to beta-mesosaprobic)}

River reaches with low inorganic nutrient input and without significant oxygen consumption; densely colonized with mostly high species diversity; water cool in summer - suitable for spawning of salmonids

\section{Class II: moderately polluted (beta-mesosaprobic)}

River reaches with moderate pollution and good oxygen supply; very high species diversity and abundance of algae, snails, entomostracans, insect larvae; aquatic plants may cover wide areas; high fish diversity

\section{Class II-III: critically polluted (beta-mesosaprobic to alpha-mesosaprobic)}

River reaches where loads of organic oxygen-depleting substances cause critical conditions; possible fishkills; decreasing number of macrophyte species; tendency to outbreaks of some plant and animal species

\section{Class III: heavily polluted (alpha-mesosaprobic)}

River reaches with heavy organic pollution; the usually low oxygen content is often insufficient for higher water organisms like fish; local sludge deposition; mass occurrences of sewage bacteria and ciliates, occasionally also sponges, leeches, and isopods; sparse aquatic vegetation

\section{Class III-IV: very heavily polluted (alpha-mesosaprobic to polysaprobic)}

River reaches with extremely restricted living conditions for higher life forms; the very high organic pollution often causes total oxygen depletion; turbidity due to suspended wastewater constituents; widespread sapropel deposits; densely colonized by chironomid larvae and oligochaetes

\section{Class IV: excessively polluted (polysaprobic)}

River reaches with excessive pollution by organic, oxygen-depleting wastewater; bacteria, flagellates, and ciliates dwell on widespread sapropel banks; often total absence of oxygen, so that survival of higher life-forms is locally and temporarily limited

respectively (Burkhardt-Holm and Bloesch 2000, Köhler et al. 2007);

- Performing long-term exotic benthos species surveys, in particular the fauna exchange triggered by the completion of the Rhine-Main-Danube Canal in 1992. Many benthos species migrate actively from the River Danube to the River Rhine, and vice versa, or they are transferred passively by water or by ships. Alien species of Ponto-Caspian origin as well as other newcomers were found, which threaten native populations by food and habitat competition (Schöll 1999);

- Elaborating Geographic Information System-based water quality and ecomorphological maps to support environmentalists, managers, and decision makers. For example, the ecomorphological map of the Drava/Mura Rivers based on EU-CEN standardized methods is an 


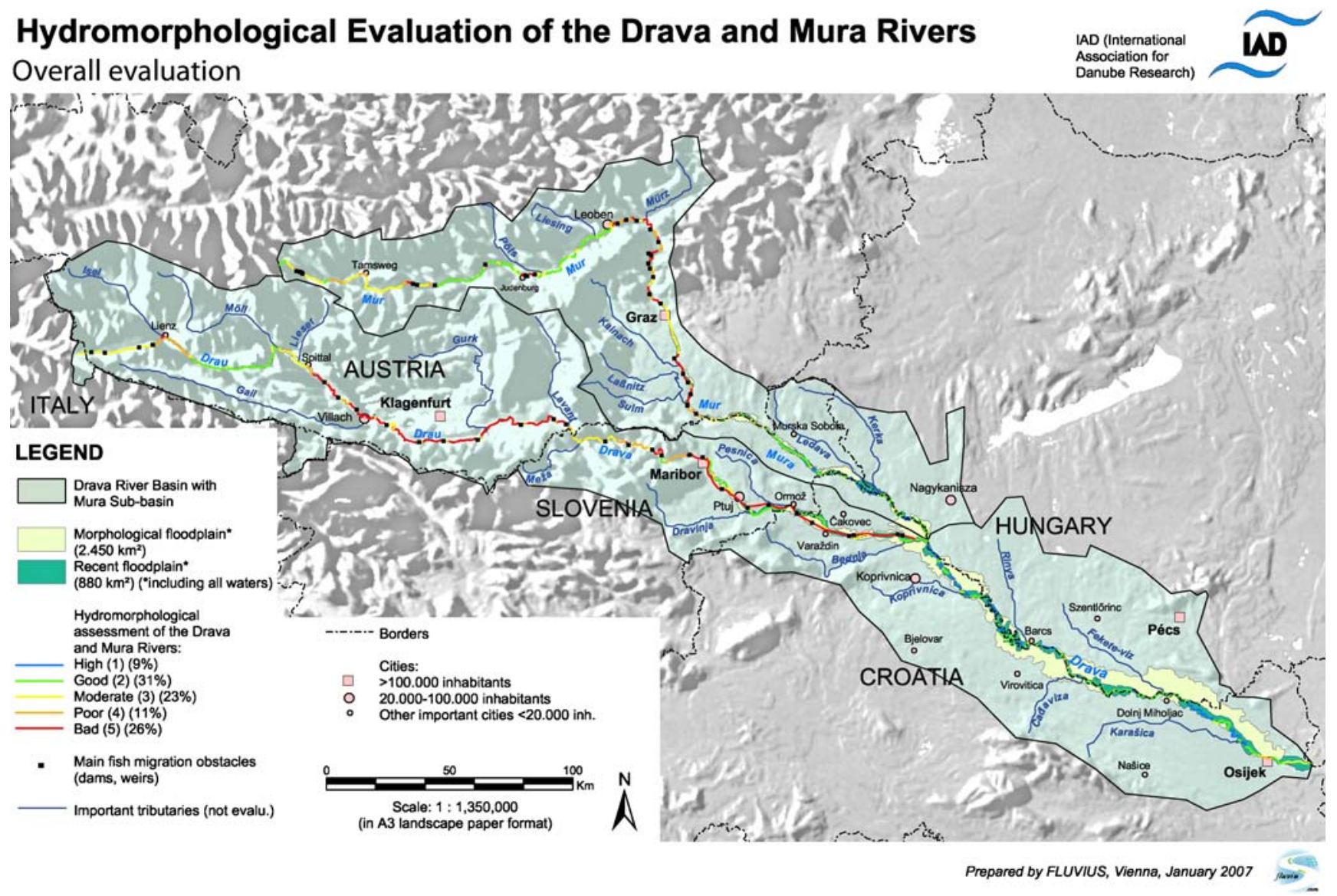

Fig. 2 Hydromorphological map of Rivers Drava and Mura (modified from Schwarz 2007). The assessment is based on continuous field data for the lower Mura down from Murska Sredice (SI) and for the entire lower Drava down from the Mura confluence. For all upper river stretches, site samples and calibration measurements were made based on the CEN conform methodology. Additionally, for the whole Drava and Mura, the results of the ICPDR Danube Analysis Report 2005 and, for Austria, the national report for the Water Framework Directive were used (risk assessment to reach the environmental objectives for the hydromorphology and HMWB analysis).In 2005,
$40 \%$ of the total river length (Drava and Mura, $1,230 \mathrm{~km}$ ) were in class I (9\%) and class II (31\%), i.e., in overall good hydromorphological condition. However, only $8 \%$ of the channel, $5-10 \%$ of the banks, and $<25 \%$ of the floodplains show natural reference conditions (best class). These relatively large areas of high ecological quality and biodiversity are located mostly along the lower river course, contrasting the strongly altered upper parts. They must be conserved and sustainably used by local agriculture and soft tourism. Major threats are hydropower and hydropeaking, navigation, and gravel exploitation as well as unsuitable constructions for flood protection indispensable tool for floodplain conservation and protection (Fig. 2; Schwarz 2007);

- Establishing macrophyte inventories and studying ecotones and flood plains. Such research leads to the understanding of the ecological function of flood plains and their role as "hot spots" of biodiversity and, in combination with hydrological studies, their function as water and nutrient retention areas (Schneider 2002, Janauer et al. 2003);

- Developing strategies and concepts for the revival of the highly threatened and endangered anadromous sturgeons along the Lower and Middle Danube, including the Stellate, Beluga, and Russian sturgeon (Fig. 3; Reinartz 2002; Reinartz et al. 2003). These "living fossils" are now the flag animal of IAD (Fig. 4), and the long-term project "Sturgeon 2020" aims at sturgeon revival along the Danube similar to the successful River Rhine program "Salmon 2000" (Bloesch et al. 2006);

- Evaluating and applying DNA-based genetic methods to elucidate microbial ecology and track sources of microbial contamination (Winter et al. 2007);

- Fostering and training the catchment approach in the Mures River Basin (Romania, Hungary) (Sandu and Bloesch 2006, 2008).

IAD scientists act also as consultants in large and detailed investigations such as the basin-wide Joint Danube 
Action Plan for the Conservation of Sturgeons (Acipenseridae) in the Danube River Basin

\section{Aim: to close the natural Sturgeon life-cycle $\rightarrow$ needs joint and simultaneous actions in the Upper, Middle and Lower Danube}

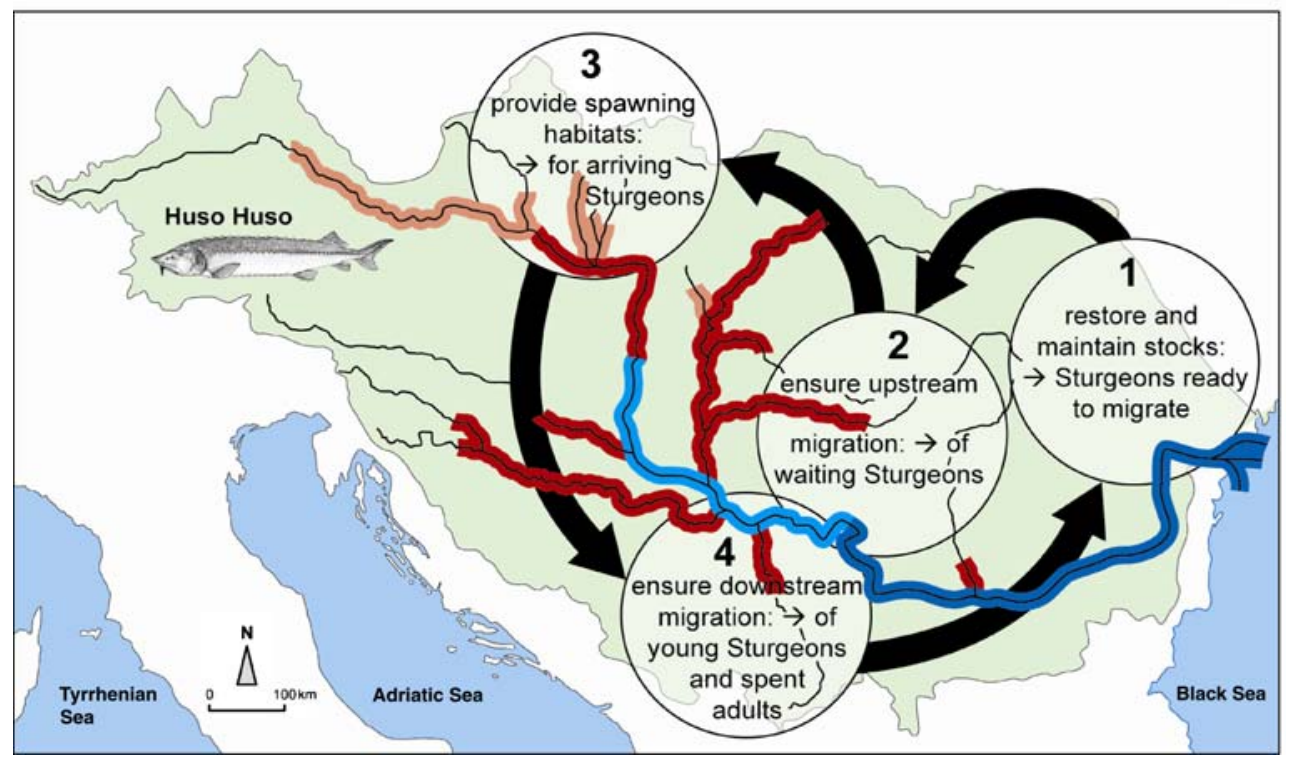

Fig. 3 Strategy and vision of the Sturgeon Action Plan (redrawn from Reinartz 2002). Main actions must be performed in parallel (simultaneously) in the Lower, Middle, and Upper Danube, such as to maintain sturgeon populations that can migrate and spawn, i.e., to encompass the entire life cycle. A step-by-step procedure based on the biological needs of sturgeons and beginning from downstream to upstream must be followed in a pragmatic way. Like any species rehabilitation program, the Sturgeon Action Plan needs to meet the biological traits of the sturgeon species and their needs of habitats.
The most urgent out of 72 actions is the installation of sturgeon passes at the two Iron Gate's hydropower dams to reopen about $800 \mathrm{~km}$ of river stretch. In accordance with the "Salmon 2000" program of the Rhine River, the vision would be to reintroduce self-sustaining sturgeon populations (with natural reproduction) in their traditional areas of distribution and to see them migrating, in 2020, upstream at least to Vienna (and may be later further up to Regensburg, for the sterlet, Acipenser ruthenus, in particular)
Surveys of ICPDR (2002), the National Park "Danube floodplains east of Vienna" (Austria) (Reckendorfer et al. 2005), and the Environmental Impact Assessment of navigation projects in the Green Corridor (Braila-Calarasi) (Bloesch et al. 2008). IAD also contributed significantly to the ICPDR Roof Report (ICPDR 2005) and Issue Paper on hydromorphological alterations (ICPDR 2007).

In summary, IAD is fostering interdisciplinary research (Bloesch et al. 2005) and promoting a basin-wide and integrated river protection strategy by providing the sound scientific basis for river managers aiming at a morphological integrity of riverine ecosystems. Since the EU accession, countries in the DRB need to fulfill environmental EU standards, all the activities of IAD are in line with the EU Water Framework Directive and other EU directives. IAD by its activities helps to strengthen the implementation of ecological measures in the DRB. The ultimate goal is achieving a "good ecological status" of the rivers, the ultimate requirement of the EU Water Framework Directive.

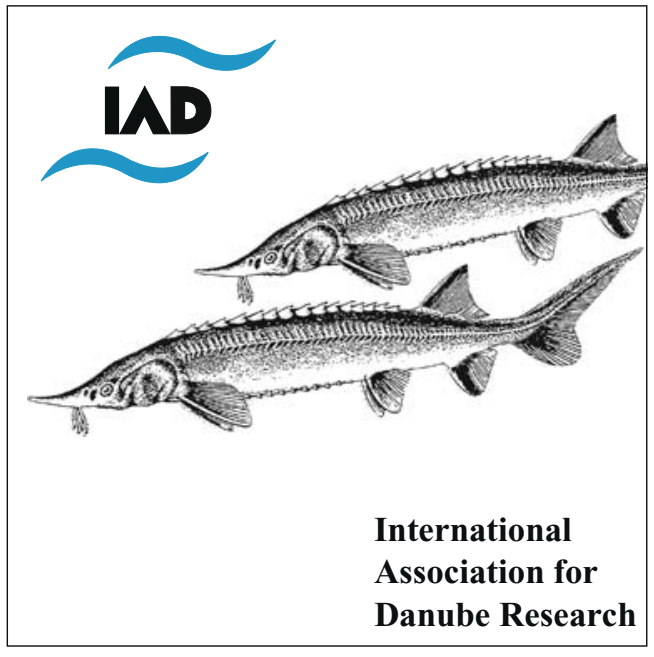

Fig. 4 The sterlet (A. ruthenus) is the flag animal of IAD and typical for the Upper Danube. IAD is not only promoting revival programs for the highly endangered sturgeons, but also strongly supports floodplain conservation and restoration 


\section{References}

Bloesch J (1999) The International Association for Danube Research (IAD): its future role in Danube research. Arch Hydrobiol Suppl. bd Large Rivers 11(3):239-259

Bloesch J (ed) (2005) River basin management: concepts and transboundary implementation (with special reference to the Danube River). Arch Hydrobiol Suppl.bd Large Rivers 16(1-2):1-328

Bloesch J, Gutknecht D, Iordache V (eds) (2005) Hydrology and limnology-another boundary in the Danube River Basin. A contribution to the IHP Ecohydrology Project Report on the International Workshop organized by the International Association for Danube Research (IAD) and sponsored by the UNESCO Venice Office. Petronell, Austria, 14-16 October 2004. IHP-VI Technical Documents in Hydrology No. 75 UNESCO, Paris

Bloesch J, Jones T, Reinartz R, Striebel B (2006) Action plan for the conservation of sturgeons (Acipenseridae) in the Danube River Basin. Reference "Nature and Environment", No. 144, Council of Europe

Bloesch J, Sandu C, Kutzenberger H, Suciu R (2008) Sturgeon migration through the Danube Green Corridor: an application of the Sturgeon Action Plan (SAP). Proceedings of the 37th IAD Conference, October 29-November 1, 2008, Chisinau, Moldova, CD-ROM

Bloesch J, Sieber U (2003) The morphological destruction and subsequent restoration programmes of large rivers in Europe. Arch Hydrobiol Suppl.bd Large Rivers 14(3-4):363-385

Burkhardt-Holm P, Bloesch J (2000) Fish as bioindicators for pollutants in the Danube River: an approach. International Association for Danube Research 33:375-382

Dalmacija B, Prica M, Ivančev - Tumbas I, van der Kooij A, Roncevic S, Krcmar D, Bikit I, Teodorovic I (2006) Pollution of the Begej Canal sediment-metals, radioactivity and toxicity assessment. Environ Int 32:606-615

Danube News (2008) Bulletin of the International Association for Danube Research (IAD), no. 17, July 2008, second last issue of the series started in 1999, 16 pp. ISSN 2070-1292. Available at http://www.iad.gs/content/publications/publications.php

Godeanu S, Popescu-Marinescu V (Hrsg) (1986) Limnologie der Donau (Bibliographie), Band II, IAD

Hein T, Janauer G, Teodorović I (eds) (2008) Transboundary river management, Water Framework Directive: selected papers presented at the 36th IAD Conference (September 4-8, 2006, Klosterneuburg, Austria) on the occasion of the 50th Anniversary of the International Association for Danube Research (IAD). Arch Hydrobiol Suppl.bd Large Rivers 18(1-2):1-360

IAD (Hrsg) (1990) Ergebnisse der Internationalen Donau-Expedition 1988 (Results of the 1988 River Danube Expedition). Ergebnisse der Donau-Forschung, Bd.1, IAD

ICPDR (2002) Joint Danube Survey. Technical Report of the International Commission for the Protection of the Danube River, Vienna, September, $261 \mathrm{pp}$

ICPDR (2005) The Danube River Basin District part A-basin-wide overview. WFD Roof Report 2004, Vienna

ICPDR (2007) Issue paper on hydromorphological alterations in the Danube River Basin Doc.No.IC/WD/265, version 12

Janauer GA, Hale P, Sweeting R (eds) (2003) Macrophyte inventory of the River Danube: a pilot study. Arch Hydrobiol Suppl.bd Large Rivers 14(1-2):1-229

Köhler HR, Sandu C, Scheil V, Nagy-Petrică EM, Segner H, Telcean I, Stan G, Triebskorn R (2007) Monitoring pollution in River Mureș, Romania, part III: biochemical effect markers in fish and integrative reflection. Environ Monit Assess 127:47-54

Kusel-Fetzmann E, Naidenow W, Russev B (1998) Plankton und Benthos der Donau (The plankton and benthos of the Danube). Ergebnisse der Donau-Forschung, Bd. 4, IAD, 376 pp
Liepolt R (1967) Limnology of the Danube. A monograph. (Die Limnologie der Donau. Eine monographische Darstellung im Auftrage der Arbeitsgemeinschaft Donauforschung der Societas Internationalis Limnologiae). E. Schweizerbart'sche Verlagsbuchhandlung, Stuttgart, $648 \mathrm{pp}$

Reckendorfer W, Schmalfuss R, Baumgartner C, Habersack H, Hohensinner S, Jungwirth M, Schiemer F (2005) The Integrated River Engineering Project for the free-flowing Danube in the Austrian Alluvial Zone National Park: contradictory goals and mutual solutions. Arch Hydrobiol Suppl 155:613-630

Reinartz R (2002) Sturgeons in the Danube River: biology/status/ conservation. Literature study conducted on behalf of IAD, Bezirk Oberpfalz and Landesfischereiverband Bayern e.V., $150 \mathrm{pp}$

Reinartz R, Bloesch J, Ring T, Stein H (2003) Sturgeons are more than caviar: a plea for revival of sturgeons in the Danube River. Arch Hydrobiol Suppl.bd Large Rivers 14(3-4):387-403

Sandu C, Bloesch J (2006) The Mureș River ecosystem - scientific background information as the basis for a catchment approach in the framework of IAD. IAD Limnological Reports 36:36-40

Sandu C, Bloesch J (2008) The transboundary Mures/Maros catchment-a review. Arch Hydrobiol Suppl.bd Large Rivers 18(12):7-23

Schmid R (1994) Limnologie und Gewässergütezustand der bayerischen Donau und ihrer wichtigsten Zubringer. Donaubasisuntersuchung 1985-1992 (The limnology and quality state of the River Danube and its main tributaries in Bavaria. Basic Danube investigation 1985-1992). Ergebnisse der Donau-Forschung, Bd.3, IAD

Schmid R (2004) Water quality of the Danube and its tributaries1995 updated and 2002. Explanations to the river quality map. (Gewässergüte der Donau und ihrer Nebenflüsse-1995 nachgeführt und 2002. Erläuterungen zur Gewässergütekarte.) State Office for Regional Water Management Regensburg and IAD General Secretary Vienna, April 2000. Wasserwirtschaftsamt Regensburg und Generalsekretariat IAD Wien, April 2004

Schneider E (2002) The ecological functions of the Danubian floodplains and their restoration with special regard to the Lower Danube. Arch Hydrobiol Suppl.bd Large Rivers 13(1-2):129-149

Schöll F (1999) Neues Leben im Fluss? Wasserwirtschaft Wassertechnik $7: 15-18$

Schwarz U (2007) Pilot study: hydromorphological survey and mapping of the Drava and Mura Rivers. IAD-Report prepared by FLUVIUS, Floodplain Ecology and River Basin Management, Vienna, $140 \mathrm{pp}$

Sládeček V (1973) System of water quality from the biological point of view. Arch Hydrobiol Beih Erg Limnol 7(I-IV):1-218

Teodorović I, Radulović S, Bloesch J (eds) (2004) IAD limnological reports, vol. 35. Proceedings of the 35th Conference Novi Sad, Serbia and Montenegro 2004, Visio Mundi Academic Press and National Committee of IAD Serbia and Montenegro

Teodorović I, Đukić N, Maletin S, Miljanović B (2000) Metal pollution index - proposal for freshwater monitoring based on trace metal accumulation in fish. Tiscia 32:55-60

Wachs B (2000) Heavy metal content in Danubian fish. Arch Hydrobiol Suppl.bd Large Rivers 11(4):557-573

Wachs B, Kopf W (1996) Biomonitoringstation und Frühwarnsystem im deutschen Einzugsgebiet der Donau. (Biomonitoring and early warning in German region Danube.) IAD Limnologische Berichte 1996 God/Vacratot

Weber E (1993) Wasserbeschaffenheit der Donau von Passau bis zu ihrer Mündung. (Water quality of the River Danube from Passau to its mouth.) Ergebnisse der Donau-Forschung, Bd.2, IAD

Winter C, Hein T, Kavka G, Mach RL, Farnleitner AH (2007) Longitudinal changes in the bacterial community composition of the Danube River: a whole-river approach. Appl Environ Microbiol 73(2):421-431 